\title{
RELICS OF THE ENEOLITHIC WYCIAZŻE GROUP AT SITE 7 IN SZARBIA, LESSER POLAND
}

\author{
S ŁAWOMIR KADROW - ANNA KRZYWDA - RYSZARD NAGLIK
}

The article presents the discovery of the first creamation cemetery of the Wyciąże group (late, Badenised phase of the Złotniki-Wyciąż group of the Polgár culture) at site 7 in Szarbia in western part of Lesser Poland. The cremation graves are accompanied by skeletons of the dead deposited in settlement features. The stylistic and typological characteristics of grave and settlement pottery as well as one ${ }^{14} \mathrm{C}$-date allow to determine the chronology of the described materials for the second half of $4^{\text {th }}$ millennium BC. The presented remains testify to the unusually long duration of Polgár culture traditions in the Kraków area, subjected to quite superficial Baden influence.

Keywords: Lesser Poland, Wyciąże group, Baden, Polgár culture, cremation graves.

\section{INTRODUCTION}

The aim of the article is to present the cemetery of the Wyciąże group (late, Badenised phase of the Złotniki-Wyciąże group of the Polgár culture) at site 7 in Szarbia in western Lesser Poland. This is the only site of the culture unit in question from which sepulchral and settlement materials were obtained.
Site 7 at Szarbia (Comm. Koniusza, Dist. Proszowice, Małopolskie Province) is located in the area covered with loess deposits. The landscape is dominated by highly segmented hills reaching up to $250 \mathrm{~m}$ a.s.l. The site is situated immediately below the top of a loess promontory, $250 \mathrm{~m}$ from the valley of a nameless watercourse and approximately $500 \mathrm{~m}$ from the Ropotek River, a left-bank tributary of the Vistula River (Naglik 2019a, 9).

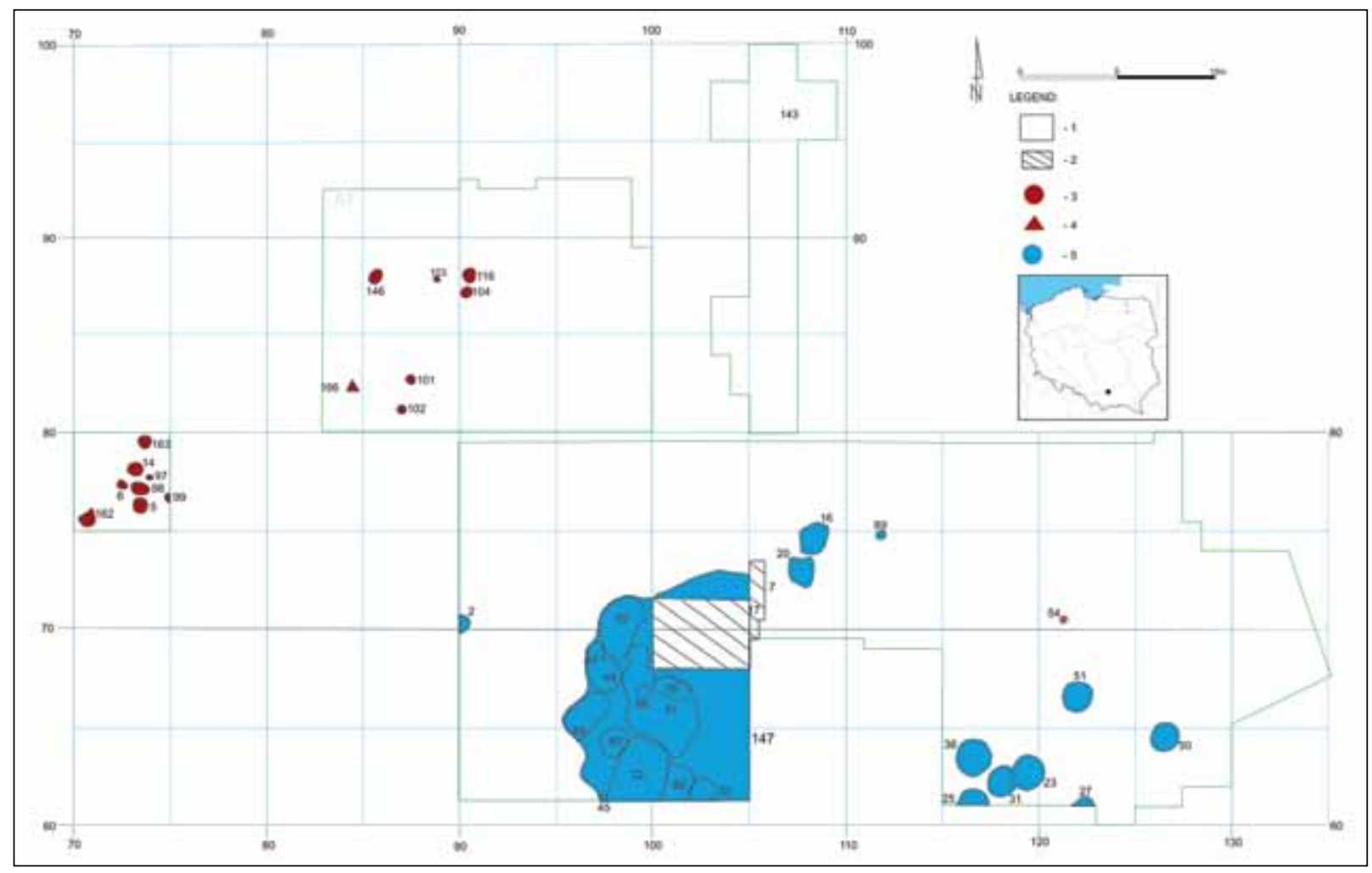

Fig. 1. Szarbia, site 7. 1 - excavated area; 2 - area, where cultural deposits were revealed, but exploration was not continued; 3-graves; 4 - grave without outline of grave pit; 5 - settlement features of Wyciąże group (after Kadrow/Krzywda/Naglik 2019). 


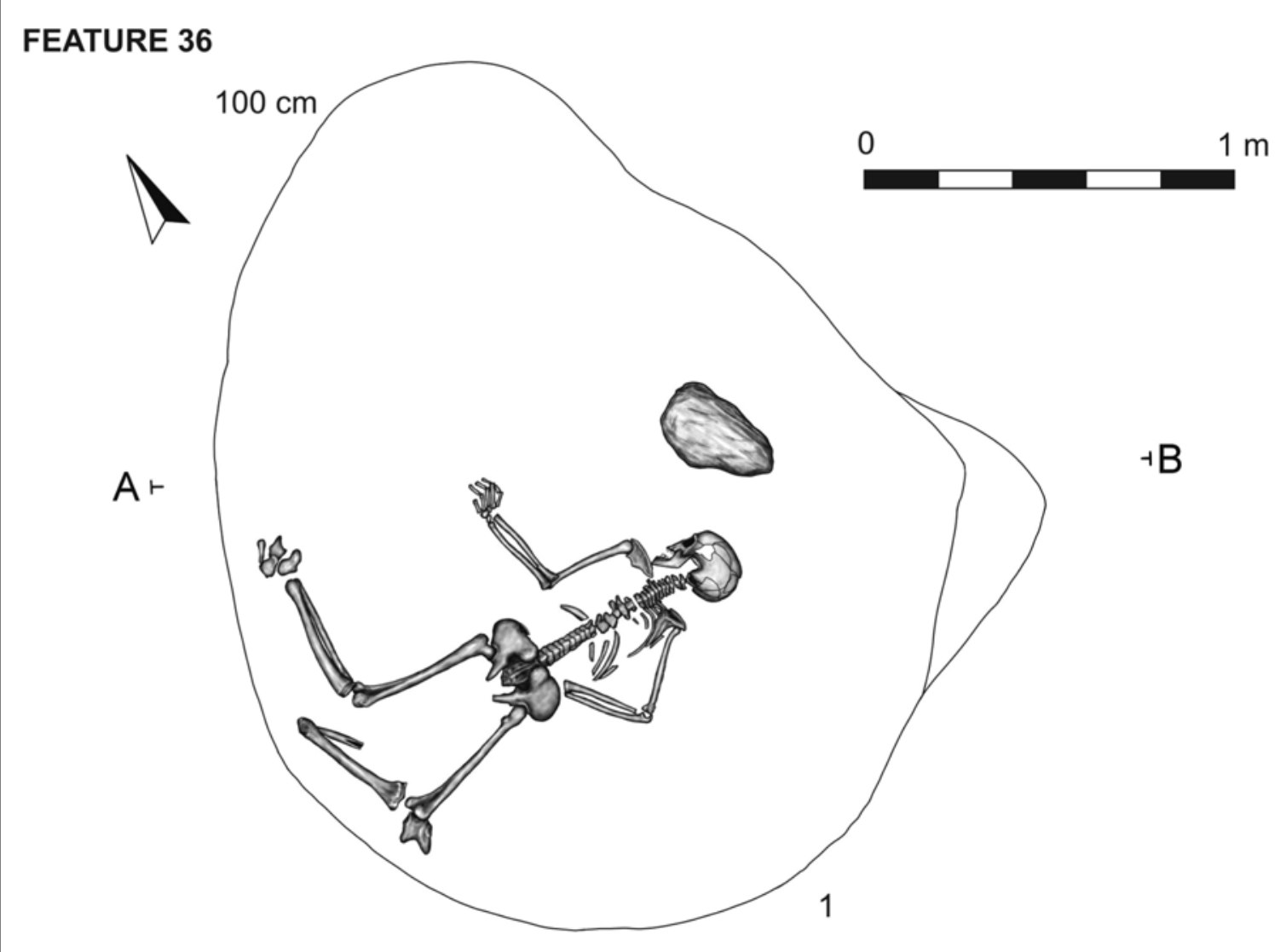

FEATURE 116

FEATURE 14

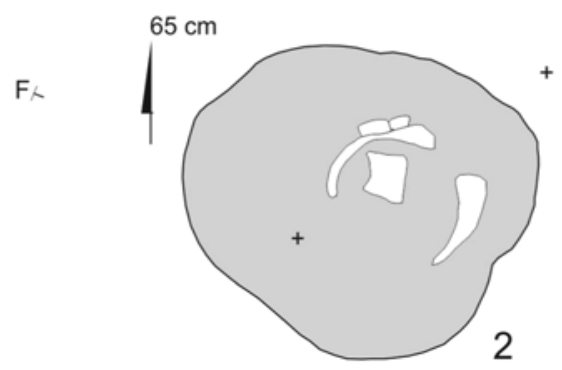

$y_{G}$
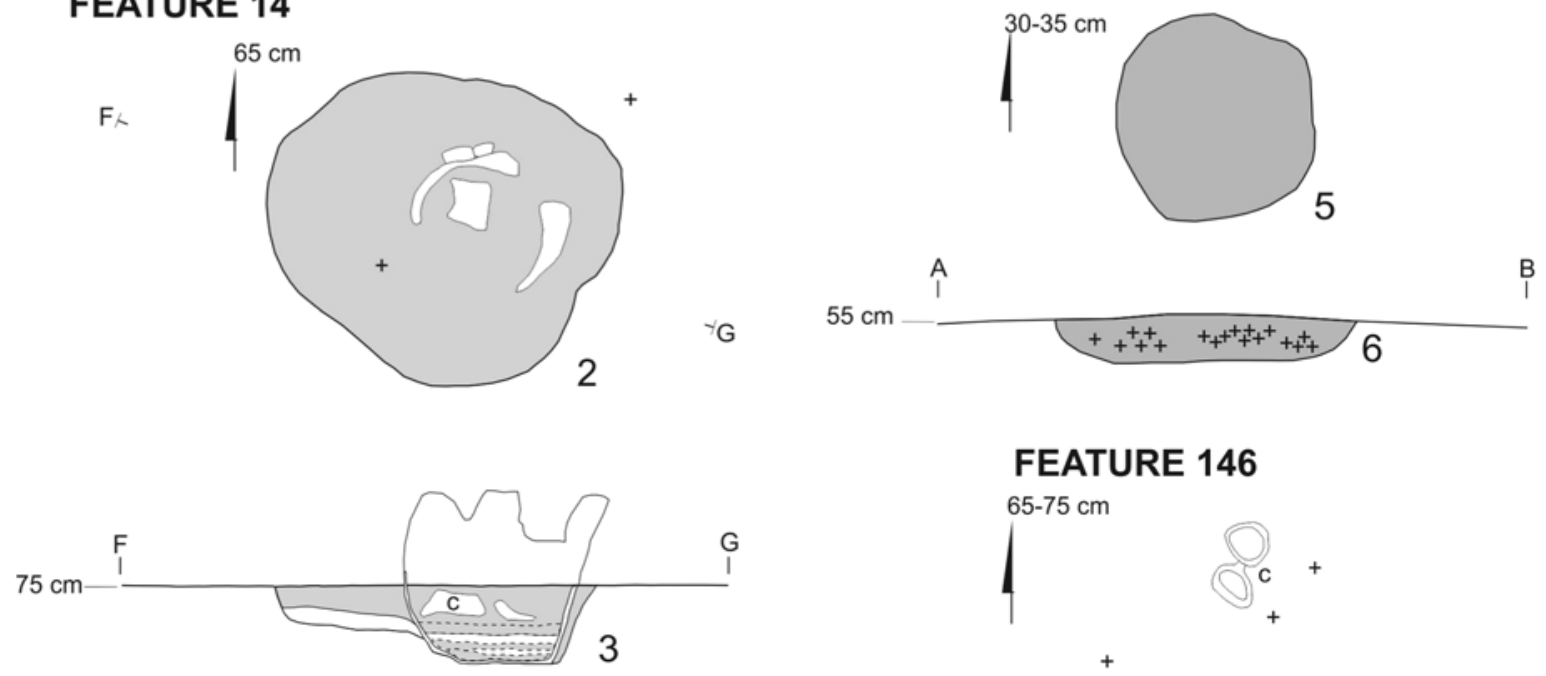

FEATURE 146

$65-75 \mathrm{~cm}$

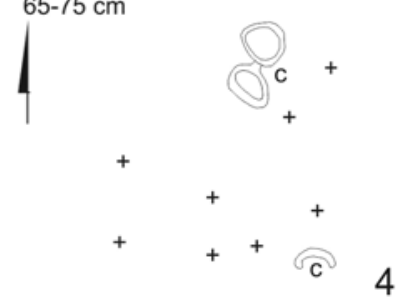

Fig. 2. Szarbia, site 7. 1 - skeleton of a woman at the bottom of settlement feature 36; 2, 3- cremation grave 14; 4 - cremation grave 146; 5, 6 - cremation grave 116 (after Kadrow/Krzywda/Naglik 2019). 
The site was discovered in 1994 during regular field surveys carried out within the Polish Archaeological Record programme (AZP 101-59/66). The survey identified several concentrations of pottery and charred bones, along with accompanying metal artefacts. In 1997, Ryszard Naglik launched rescue excavations (continued in 1999-2001).

In addition to the relics of the Eneolithic group of Wyciąże, which are of interest to us here, there has been discovered above all the Early Roman period cemetery, including two barrows with 'princely' graves (Naglik 2019b). In addition, modest sets of remains belonging to several Neolithic and Early Bronze Age cultures were obtained from this site (Kadrow/Krzywda/Naglik 2019, 23-119).

\section{CEMETERY OF WYCIAZŻE GROUP - CREMATION GRAVES}

In the western fringes of the area investigated in site 7 at Szarbia, 14 cremation burials in pits were discovered (Fig. 1), which were either unfurnished (10 graves: 5, 6, 97, 98, 99, 102, 103, 104, 162, 163; cf. Kadrow/Krzywda/Naglik 2019, table 1) or were furnished with ceramic vessels characteristic for the Wyciąże group (4 graves: 14, 101, 116, 146; cf. Kadrow/Krzywda/Naglik 2019, table 2; 3). In addition, large fragments of two vessels found in Przeworsk culture ditch 138-47 (cf. Kadrow/Krzywda/Naglik2019, table 16) were interpreted as remains of a damaged, fifth grave.

All of them were identified immediately beneath the topsoil, at depths varying from 30 to $65 \mathrm{~cm}$. Outlines of oval pits were discernible at the levels of discovery or above the graves' bottoms only in seven cases (graves: 5, 14, 104, 116, 146, 162, 163; cf. Kadrow/Krzywda/Naglik 2019, table 1-4), of which three were furnished graves.

Oval outlines of the grave pits were marked by the distribution of cremated human bones. Dimensions of graves varied from $10 \times 25 \mathrm{~cm}$ to $70-110 \times 130 \mathrm{~cm}$, and their depths from 40 to $100 \mathrm{~cm}$. In terms of thickness the fills of the majority of the graves did not exceed $15 \mathrm{~cm}$. In the shallowest graves only a thin layer of cremated bones was identified at the bottom. One can notice a distinct correlation between the size and depth of graves: the shallowest features (up to $10 \mathrm{~cm}$ thick) were the smallest (10-20 x 30-35 cm). Thus, these are only bottom parts of graves damaged by ploughing and natural erosion. Grave 166 was preserved without outline of grave pit.

The features in question yielded only single, tiny pieces of charred wood. Only in one grave did human bones form a compact cluster of a shape suggesting their original deposition in an organic container (grave 5; cf. Kadrow/Krzywda/Naglik 2019, table 1). In other graves, bones were spread throughout the pit, although usually with slightly more of them in the central part.

The distribution of bones in graves furnished with pottery was the same. Only in one vessel - the pot from grave 14 - was found one cremated human bone, which got there after a part of the pot's rim was broken and pushed inside. In two graves, the vessels were placed at the bottom of the pit - the pot in the deepest grave 14 (Fig. 2: 2, 3) and the lower part of an undetermined vessel (with the upper part damaged by ploughing) in one of the shallowest graves (feature 101; cf. Kadrow/Krzywda/Naglik 2019, table 3). In the remaining two furnished graves in which grave goods were found up to $10 \mathrm{~cm}$ above the bottom, the vessels were placed partly on the bone layer: the jug/pitcher in grave 116 (Fig. 2: 5, 6) and two adjacent scoops in grave 146 (Fig. 2: 4).

Both groups of graves - unfurnished and furnished with vessels - show similarities in terms of shape, size, pit depth, and manner of deposition of bones. The graves were recorded over a compact area separated into two groups by a strip of unexplored land. These graves differ considerably in form from Przeworsk culture burials in pits which also occur on the site. In the latter, bones always form compact clusters in the central parts of graves, and are mixed with grave goods. This allows for an assumption that the discussed four graves provided with Wyciąże group vessels (along with the alleged fifth one in the Przeworsk culture ditch) and ten unfurnished graves originate from the same chronological period.

Given the shallow depth and thickness of the fills, the absence of furnishings most likely stems from damage caused by ploughing and erosion. However, this does not rule out the possibility that some of these burials may have indeed been devoid of furnishings.

The limited area of the excavations (Fig. 1) does not allow the actual size of the cemetery to be estimated. One can only conclude that the number of graves increases towards the south-east.

\section{SKELETONS IN SETTLEMENT FEATURES}

The discovered fragment of the Eneolithic settlement of the Wyciąże group (Fig. 1) encompassed 14 pits and a part of a very extensive claypit complex (feature 147; cf. Kadrow/Krzywda/Naglik 2019, fig. 6; table 14). Human skeletons were found in two pits: one complete in pit 36 (Fig. 2: 1) and fragments of another two in pit 23. 


\section{FEATURE 14}

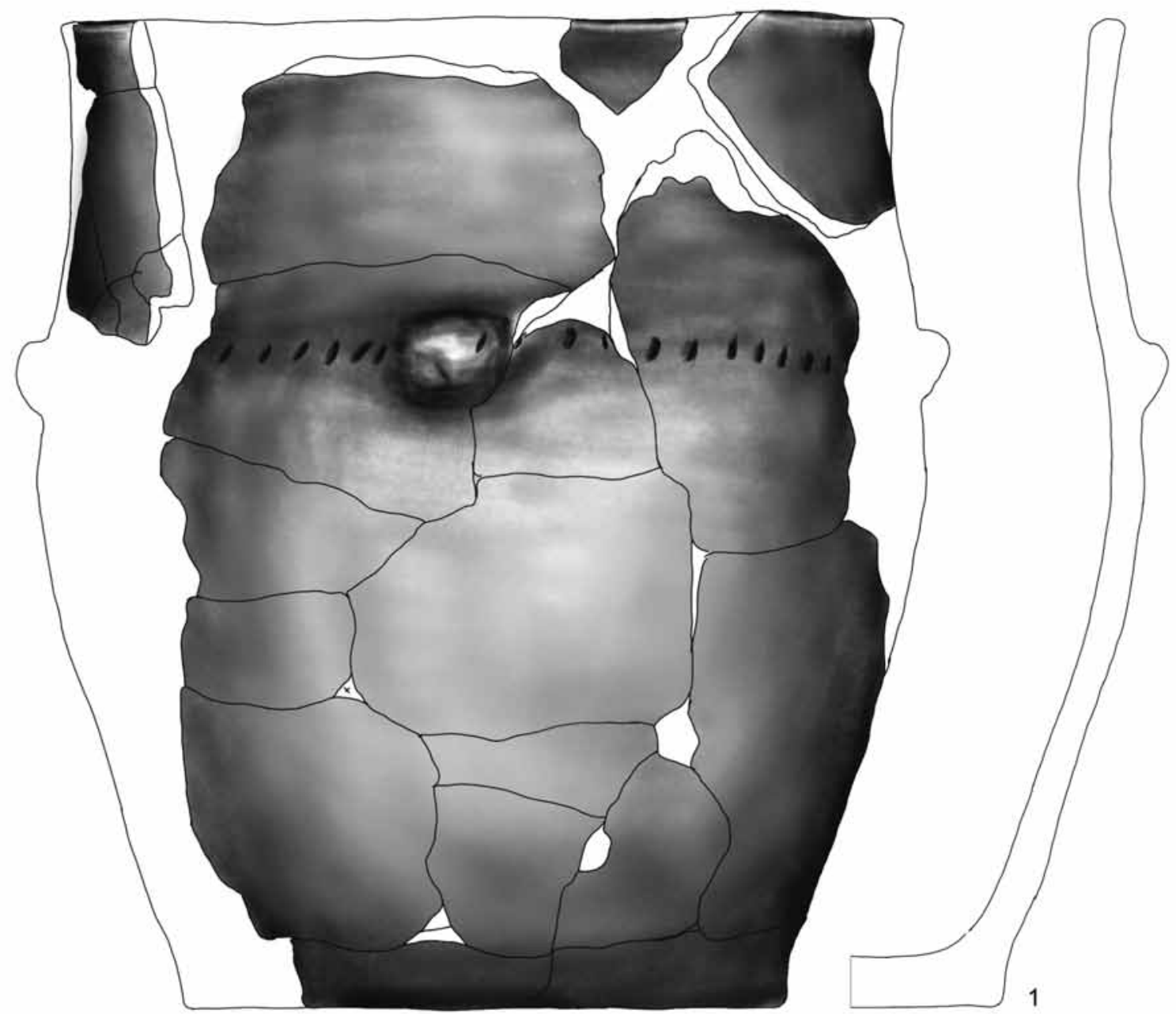

\section{FEATURE166}

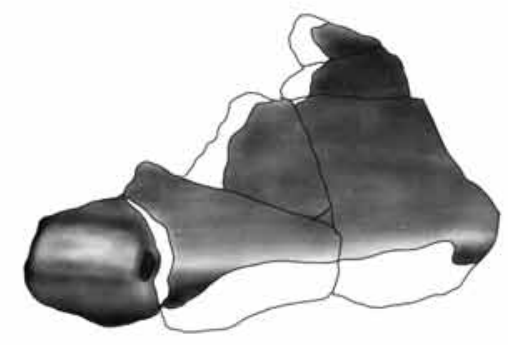

0

$10 \mathrm{~cm}$
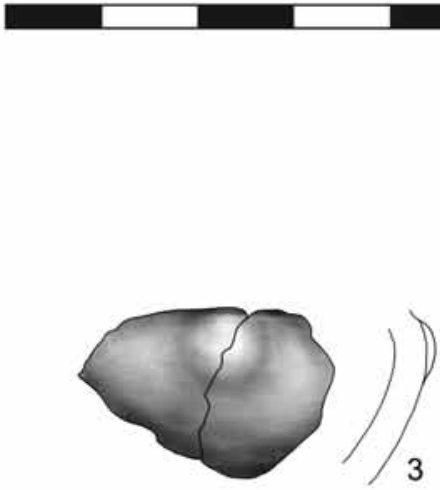

Fig. 3. Szarbia, site 7. Pottery of Wyciąże group (after Kadrow/Krzywda/Naglik 2019). 
The skeleton of a woman was found at the bottom of pit 36 (Fig. 2: 1). It was lying in prone position with the arms bent at right angles. The legs, bent in an analogical manner, were situated at the edge of the pit's bottom. The head was situated at the axis of symmetry of the entrance. The woman, aged 30-40, was approximately $148 \mathrm{~cm}$ tall. The position of the skeleton (Fig. 2: 1) suggests the deceased had been thrown down into the pit head first - the position of her legs probably results from them having slid down along the pit's sloped ceiling. The homogenous (?) nature of the fill indicates the pit was filled back deliberately, in a single episode.

Fragments of human skeletons were also uncovered in neighbouring pit 23 . The poorly preserved skull and a rib fragment belonging to a child at the age of 1-2 years and a phalanx of an adult individual were found lying on the layer of daub, pottery, and animal bones which covered the bottom of the pit (Kadrow/Krzywda/Naglik 2019, fig. 5). The poor preservation and incompleteness of the human bones are additional arguments against regarding the pit as the place of their original deposition. Analogical finds of human bones in pits within the Baden culture settlement at Bronocice are interpreted by J. Kruk and S. Milisauskas as 'rather thrown-in than placed'. They notice that the positions in which the skeletons were found were coincidental (Kruk/ Milisauskas 1981, 79).

\section{POTTERY ITEMS FOUND IN CREMATION GRAVES}

Barrel-shaped pot (Fig. 3: 1) with short neck, decorated with a horizontal row of oblique nail impressions and two (?) knobs in the upper part of the body (grave 14). The lower body of a vessel (Kadrow/Krzywda/Naglik 2019, table 3: 1) of undetermined type (grave 101). A jug with a flat handle, with four knobs in the upper part of the body (Fig. 4: 1) as the only decoration (grave 116). Two scoops (Fig. 4: 2,3) with a flat handle, undecorated (grave 146). Fragmentarily preserved bowl (feature 138-47; cf. Kadrow/Krzywda/Naglik 2019, table 16: 1). Fragmentarily preserved amphora with a round-sectioned handle on the shoulder (Fig. 3: 2, 3) from grave 166.

\section{GENERAL CHARACTERISTICS OF POTTERY FROM GRAVES AND SETTLEMENT FEATURES}

The collection of Wyciąże group pottery on site 7 at Szarbia is comprised of the following: scoops, jugs, amphoras, beakers, pots, bowls, and vases. The majority of the vessels closely relates to the Polgár tradition, to the Bodrogkeresztúr culture in particular. This is manifested by the characteristically emphasised transition between the body and the neck (Kadrow/Krzywda/Naglik 2019, table 7: 1), as in vessels of the Wyciąże-Złotniki group (e. g. Kozłowski 2006, fig. 3; 4; Kulczycka-Leciejewiczowa 1979, fig. 58: 15, 16). The same can be said about small handles placed at the height of the rim (Kadrow/Krzywda/Naglik 2019, table 15: 1). The shapes of scoops (Fig. 4: 2, 3) and jugs (Fig. 4: 1) are entirely Polgár, while the fact they are provided with handles indicates a relationship with a tradition which first became evident in Transdanubia in the Proto-Baden culture of Balaton-Lasinja (cf. Kadrow 2009, 183; Kalicz 1991, 355, fig. 3; 4), contemporary with the Bodrogkeresztúr culture on the Great Hungarian Plain (Kalicz 1980, 74).

With the same tradition one should link a tendency towards spare ornamentation of vessels, including the application of single knobs (Kadrow/ Krzywda/Naglik 2019, table 5: 2) and fingertip impressions, while rows of fingertip and fingertip and nail (Kadrow/Krzywda/Naglik 2019, table 15) impressions, rich incised decoration, and smearing the surfaces with a brush can all be perceived as Baden influences (cf. e. g. Bober 2015, pl. I-XXIII).

The vast bulk of the pottery represents type of technology, in which the ceramic mass is tempered with small or moderate amounts of finely crushed sherds. External surfaces of vessels are even, often slightly smoothed. Walls are two- or three-coloured in section. This technology is characteristic of early Eneolithic groups representing mainly the Polgár complex (cf. Kadrow/Rauba-Bukowska 2017, fig. 6; 7), the Wyciąże-Złotniki group included. Sherds representing another type of technology, with admixtures of dry clay, are much less numerous. Tempers of this kind were frequently used by potters from the Baden cultural circle, and less often in Danubian cultures (cf. Kadrow 1990, table 2).

\section{CHRONOLOGY OF WYCIAZŻE GROUP}

More than 70 years have passed since the descriptions of ceramic inventories from sites at Wyciąże and Książnice Wielkie (Burchard/Ekier 1964, 181-291) impelled Janusz Krzysztof Kozłowski to distinguish and characterise what he called the Wyciąże-Książnice group (Kozłowski 1968; 1971), which combined Polgár and Baden traits. Similar materials were later identified at Pleszów (Godłowska 1976; 1979, 305, 306, fig. 184). Today, nine sites (including those mentioned above) of this cultural unit are known (Zastawny 2015a, 128, fig. 2B). 


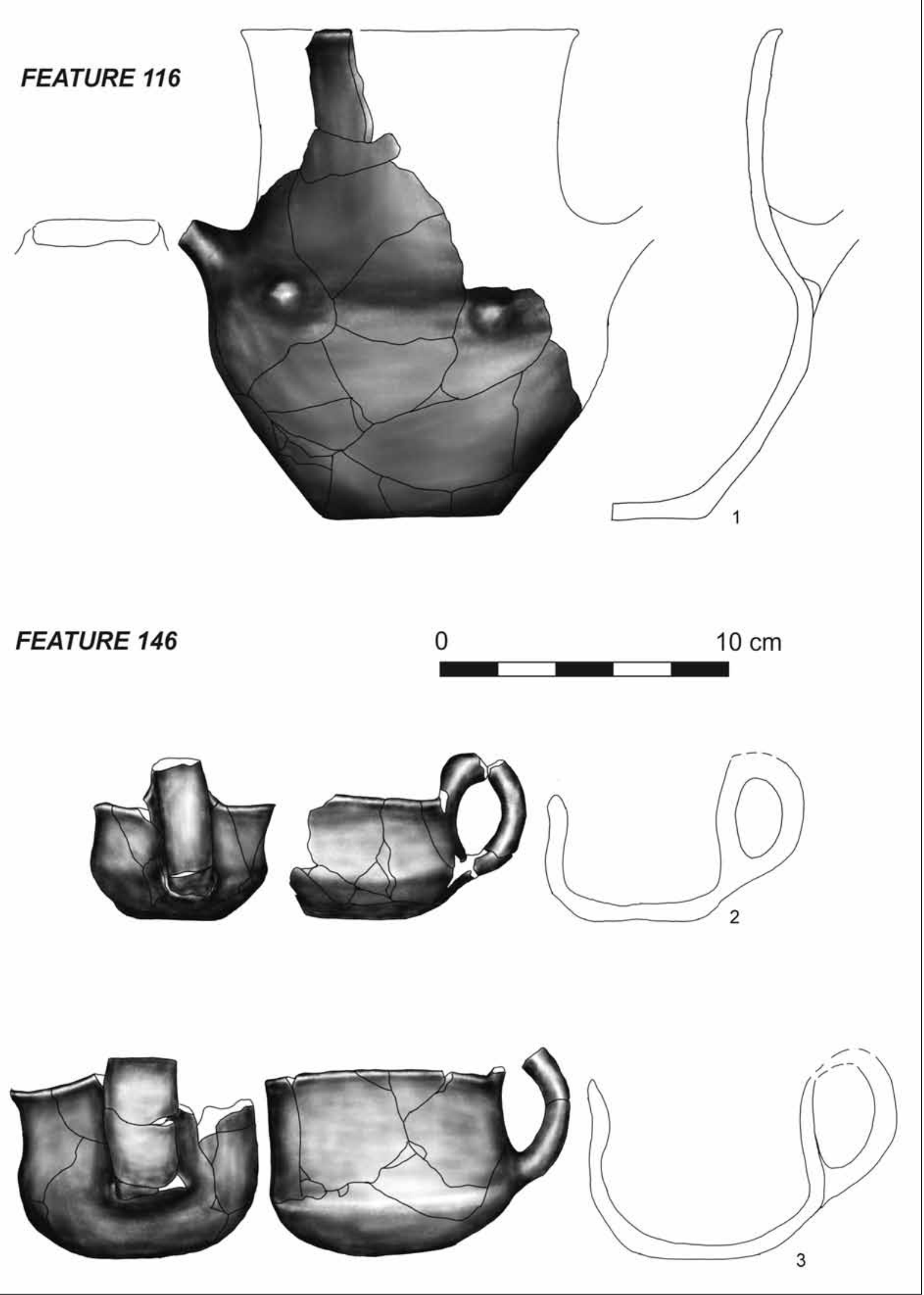

Fig. 4. Szarbia, site 7. Pottery of Wyciąże group (after Kadrow/Krzywda/Naglik 2019). 


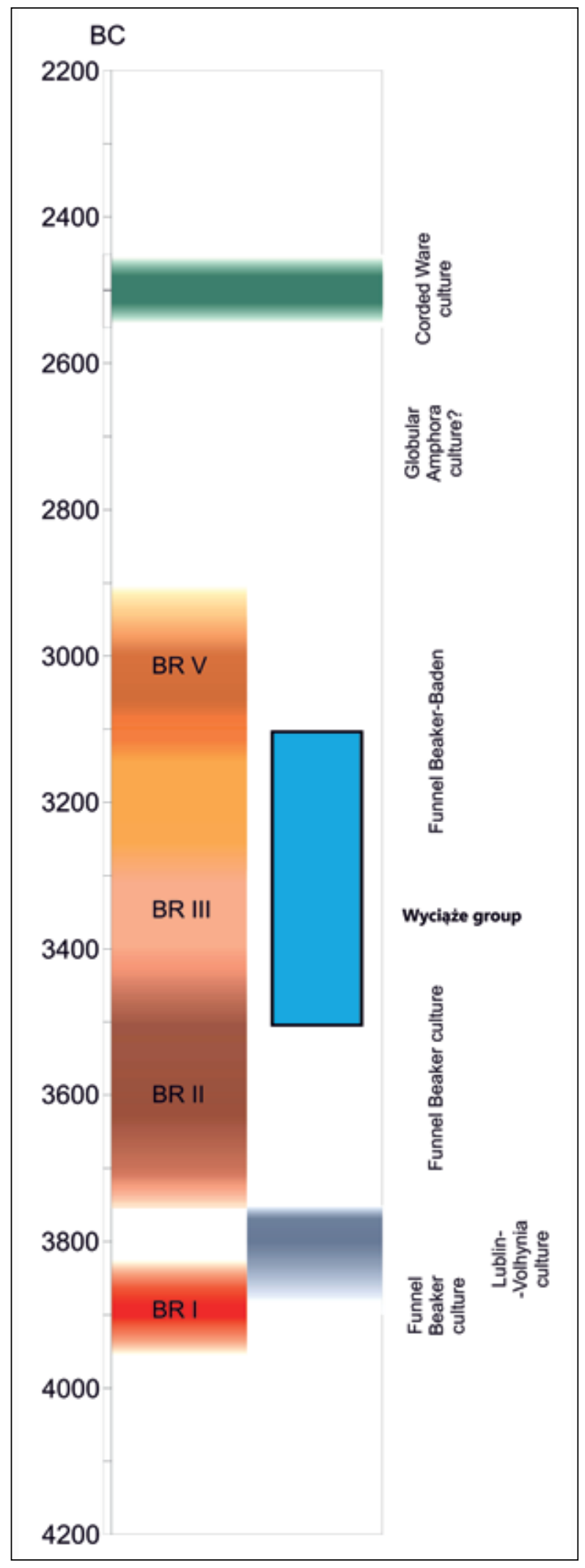

Fig. 5. Absolute chronology of the Wyciąże group on the background of Funnel Beaker culture sequence at Bronocice and other culture units in western Lesser Poland (partly after Włodarczak 2020, in print).
Since the specificity of the (epi- or late-) Polgár ceramic materials exposed to Baden influences is best illustrated by materials from Wyciąże (Bober 1998, pl. III; 2015, pl. 1; Furholt 2009, 339), the unit has come to be described as the Wyciąże group (Godtowska 1979; Zastawny 2015a, 125).

Among the currently known sites of the cultural unit in question, only site 7 at Szarbia yielded both settlement and sepulchral materials. This corroborates a view expressed in the past about a primarily Polgár nature of the Wyciąże group, with rather superficial Baden influences (Godłowska 1979, 305, 306; Zastawny 2015a, 125, 128), and with closest references to the Wyciąże-Złotniki group of the Polgár culture.

One of the most important Baden elements are cups with handles attached immediately over the rim, Boleráz in style and most often undecorated (Furholt 2009, 339; Peška 2015, fig. 2: 11, 12). Another extremely important Baden element at Szarbia is the cremation burial rite. Added to this picture is a find from the settlement, where the skeleton of a woman who died between 3331 and 3069 BC was found in pit 36 (probability range of $68.2 \%$ for the measurement of ${ }^{14} \mathrm{C}$ contents in a human bone sample from feature 36 - Poz-115836 $4480 \pm 35 \mathrm{BP}$ ).

The position of the skeleton suggests that the deceased was thrown into the pit with her face to the ground. Thus, this act of deposition can only with some restrictions be regarded as a 'normal' burial. Previously, only one inhumation burial of the mentioned cultural unit has been known, from site 76 at Kraków-Branice. It held bone remains of one individual, placed in a supine position and furnished with ceramic vessels and flint artefacts (Zastawny 2009).

The coexistence of various forms of inhumation with cremation (urned and urnless) is a typical phenomenon among peripheral groups of the Baden complex (cf. e. g. Horváthová et al. 2017, 11-14; Meyer 1995, 167-169), with undisputed predominance of cremation in the central areas of this complex (Kalicz 1963).

The chronology of the Wyciąże group (Fig. 5) is determined by a few ${ }^{14} \mathrm{C}$-dates (Furholt 2009; Furholt) Machnik 2006; Valde-Nowak et al. 2015) and by broader deliberations they gave ground to, which point to a timespan of 3500-3350 BC (Horvath/Svingor 2015, 30). Other scholars place the Wyciąże group within the younger phase of the Proto-Baden horizon, which means within 3500-3100 BC (cf. Zastawny $2015 a, 145 ; 2015 b$ ). 


\section{CONCLUSIONS}

The discoveries at site 7 in Szarbia allow a better definition of the Wyciąże group. In addition to the Badenized Funnel Beaker culture assemblages, known primarily from the Bronocice IV and Bronocice V phases (Kruk/Milisauskas 1983), this group is a characteristic example of transcultural integration, typical of globalization processes at various levels (Feinman 2017, 43). An integrating factor in the $2^{\text {nd }}$ half of $4^{\text {th }}$ millennium BC in the Carpathian Basin and in the adjacent areas was the Baden culture. In the areas north of the Carpathians, some Funnel Beaker culture groups (Bronocice IV-V) and Polgár culture (the Wyciąże group) were subject to Badenization processes.

\section{LITERATURE}

Bober 1998 - J. Bober: Najnowsze materiały kultury ceramiki promienistej ze stanowiska 5, 5A, 5B w Krakowie-Nowej Hucie (Wyciąże). Materiały Archeologiczne Nowej Huty 21, 1998, 7-26.

Bober 2015 - J. Bober: Pottery of the Baden Culture in Lesser Poland on the Basis of Findings in the Kraków-Nowa Huta Area. In: M. Nowak/A. Zastawny (eds.): The Baden culture around the Western Carpathians. Via Archaeologica. Źrodła z badań wykopaliskowych na trasie autostrady A4 w Małopolsce. Kraków 2015, 221-260.

Burchard/Ekier 1964 - H. Burchard/B. Ekier: Osadnictwo kultury czasz lejowatych w Książnicach Wielkich, pow. Kazimierza Wielka. In: S. Nosek (red.): Studia i materiały do badań nad neolitem Małopolski. Wrocław 1964, 191-327.

Feinman 2017 - G. M. Feinman: Economic aspects of globalization in the past material world. In: T. Hodos (ed.): The Routledge Handbook of Archaeology and Globalization. London - New York 2017, 42-53.

Furholt 2009 - M. Furholt: Die nördlichen Badener Keramikstile im Kontext des mitteleuropäischen Spätneolithikums (3650-2900 v. Chr.). Studien zur Archäologie in Ostmitteleuropa 3. Bonn 2009.

Furholt/Machnik 2006 - M. Furholt/J. Machnik: Iwanowice Babia Gora I and the settlement with Baden ceramics in Little Poland. Questions concerning their duration. Sprawozdania Archeologiczne 58, 2006, 325-354.

Godłowska 1976 - M. Godłowska: Próba rekonstrukcji rozwoju osadnictwa neolitycznego w rejonie Nowej Huty. Materiały Archeologiczne Nowej Huty 5, 1976, 7-181.

Godłowska 1979 - M. Godłowska: Plemiona kultury ceramiki promienistej. In: W. Hensel/T. Wiślański (red.): Prahistoria ziem polskich 2. Neolit. Wrocław 1979, 302-317.

Horvath/Svingor 2015 - T. Horvath/E. Svingor: The Spatial and Chronological Distribution of the so-called 'Baden Culture'. In: M. Nowak/A. Zastawny (eds.): The Baden culture around the Western Carpathians. Via Archaeologica. Źrodła z badań wykopaliskowych na trasie autostrady A4 w Małopolsce. Kraków 2015, 19-74.

Horváthová et al. 2017 - E. Horváthová/A. Zastawny/ M. Čurný/A. Szczepanek: Burials of the Baden culture from Vel'ky Šariš and their importance for the investigation of the studied culture in the northern Tisza region. Slovenská archeológia 65, 2017, 1-22.

Kadrow 1990 - S. Kadrow: Osada neolityczna na stan. nr 16 w Rzeszowie na Osiedlu Piastów. Sprawozdania Archeologiczne 41, 1990, 9-76.

Kadrow 2009 - S. Kadrow: W odpowiedzi Tomaszowi Chmielewskiemu o fazie rzeszowskiej raz jeszcze. Przeglad Archeologiczny 57, 2009, 173-189.
Kadrow/Krzywda/Naglik 2019 - S. Kadrow/A. Krzywda/ R. Naglik: Szarbia, site 7, Comm. Koniusza. Graves and settlements from the Neolithic to the Early Bronze Age. In: R. Naglik (ed.): Szarbia, site 7, Comm. Koniusza. Settlements and Cemeteries from Neolithic to the Roman Period. Biblioteka Muzeum Archeologicznego w Krakowie 9. Kraków 2019, 23-119.

Kadrow/Rauba-Bukowska 2017 -S. Kadrow/A. Rauba-Bukowska: The selection of ceramic raw material: convenience or a technological idea? A case study of the Danubian cultures north of the Carpathians. Archeologické rozhledy 69, 2017, 261-280.

Kalicz 1963 - N. Kalicz: Die Peceler (Badener Kultur) und Anatolien. Studia Archaeologica 9. Budapest 1963.

Kalicz 1980 - N. Kalicz: Clay Gods. The Neolithic Period and the Copper Age in Hungary. Budapest 1980.

Kalicz 1991 - N. Kalicz: Beiträge zur Kenntnis der Kupferzeit im ungarischen Transdanubien. In: J. Lichardus (Hrsg.): Die Kupferzeit als historische Epoche. Saarbrücken 1991, 347-386.

Kozłowski 1968 - J. K. Kozłowski: Materiały neolityczne i eneolityczne odkryte na stanowisku Nowa Huta - Wyciąże I (badania w latach 1950-1952). Materiały Archeologiczne Nowej Huty 1, 1968, 13-90.

Kozłowski 1971 - J. K. Kozłowski: Niektóre aspekty genezy kultury ceramiki promienistej w Polsce. Światowit 32, 1971, 27-60.

Kozłowski 2006 - J. K. Kozłowski: Grupa Wyciąże-Złotniki i bezpośrednie oddziaływania poźnopolgarskie. In: M. Kaczanowska (red.): Dziedzictwo cywilizacji naddunajskich: Małopolska na przełomie epoki kamienia i miedzi. Biblioteka Muzeum Archeologicznego w Krakowie 1. Kraków 2006, 53-61.

Kruk/Milisauskas 1981 - J. Kruk/S. Milisauskas: Wyżynne osiedle neolityczne w Bronocicach, woj. kieleckie. Archeologia Polski 26, 1981, 65-113.

Kruk/Milisauskas 1983 - J. Kruk/S. Milisauskas: Chronologia absolutna osadnictwa neolitycznego z Bronocic, woj. kieleckie. Archeologia Polski 28, 1983, 257-320.

Kulczycka-Leciejewiczowa 1979 - A. Kulczycka-Leciejewiczowa: Pierwsze społeczeństwa rolnicze na ziemiach polskich. Kultury kręgu naddunajskiego. In: W. Hensel/T. Wiślański (red.): Prahistoria ziem polskich 2. Neolit. Wrocław 1979, 19-164.

Mayer 1995 - C. Mayer: Klassische Badener Kultur. In: E. Lenneis/C. Neugebauer-Maresch/E. Ruttkay (Hrsg.): Jungsteinzeit im osten Österreichs. St. Pölten - Wien 1995, 161-177.

Naglik 2019a - R. Naglik: Szarbia, site 7, Comm. Koniusza. Introductory remarks. In: R. Naglik (ed.): Szarbia, site 7, 
Comm. Koniusza. Settlements and Cemeteries from Neolithic to the Roman Period. Biblioteka Muzeum Archeologicznego w Krakowie 9. Kraków 2019, 9-22.

Naglik 2019b - R. Naglik: Szarbia, site 7, Comm. Koniusza. Przeworsk culture cemetery. In: R. Naglik (ed.): Szarbia, site 7, Comm. Koniusza. Settlements and Cemeteries from Neolithic to the Roman Period. Biblioteka Muzeum Archeologicznego w Krakowie 9. Kraków 2019, 201-315.

Peška 2015 - J. Peška: A Small Contribution to the Knowledge of the Baden Culture in Moravia and the Present State of Research. In: M. Nowak/A. Zastawny (eds.): The Baden culture around the Western Carpathians. Via Archaeologica. Źrodła z badań wykopaliskowych na trasie autostrady A4 w Małopolsce. Kraków 2015, 95-118.

Valde-Nowak et al. 2015 - P. Valde-Nowak/A. Gil-Drozd/ A. Kraszewska/M. Paternoga: The Proto-Boleráz Grave in the Western Beskidy Mts., Lesser Poland. In: M. Nowak/A. Zastawny (eds.): The Baden culture around the Western Carpathians. Via Archaeologica. Źródła z badań wykopaliskowych na trasie autostrady A4 w Małopolsce. Kraków 2015, 371-380.

Manuscript accepted 19. 6. 2020

Translated by Piotr Godlewski with the participation of the authors Súhrn preložila Erika Makarová

Prof. dr hab. Sławomir Kadrow

Institute of Archaeology

Rzeszów University

ul. Moniuszki 10

PL - 35-015 Rzeszów

slawekkadrow@gmail.com

Anna Krzywda MA

ayka@pradzieje.pl
Włodarczak 2020, in print-P. Włodarczak: Barbara Burchard and studies on the chronology of the Funnel Beaker culture in Lesser Poland. Sprawozdania Archeologiczne $72 / 2,2020$, in print.

Zastawny 2009 - A. Zastawny: Grupa Wyciąże. In: A. Czekaj-Zastawny (red.): Obrzadek pogrzebowy kultur pochodzenia naddunajskiego w neolicie Polski południowo-wschodniej (5600/5500-2900 BC). Kraków 2009, 449-552.

Zastawny 2015a - A. Zastawny: The Baden complex in Lesser Poland - horizons of cultural influences. In: M. Nowak/A. Zastawny (eds.): The Baden culture around the Western Carpathians. Via Archaeologica. Źrodła z badań wykopaliskowych na trasie autostrady A4 w Małopolsce. Kraków 2015, 119-150.

Zastawny 2015b - A. Zastawny: Absolute chronology of the Baden culture in Lesser Poland - new radiocarbon dates. In: M. Nowak/A. Zastawny (eds.): The Baden culture around the Western Carpathians. Via Archaeologica. Źrodła z badań wykopaliskowych na trasie autostrady A4 w Małopolsce. Kraków 2015, 191-219.

Ryszard Naglik MA

Archaeological Museum

ul. Senacka 3

PL - 31-002 Kraków

naglik@ma.krakow.pl 


\title{
Pamiatky eneolitickej skupiny Wyciąże na nálezisku 7 v Szarbii, v Malopol’sku
}

\author{
Sławomir Kadrow - Anna Krzywda - Ryszard Naglik
}

\section{SÚHRN}

Ciel’om článku je prezentácia pohrebiska skupiny Wyciąże (neskorá, badenizovaná fáza skupiny Złotniki-Wyciąż polgárskej kultúry) na nálezisku 7 v Szarbii v západnom Malopol'sku. Ide o jedinú lokalitu tejto kultúry, z ktorej bol získaný sepulkrálny (kremačný) a sídliskový materiál.

V západných okrajoch preskúmanej oblasti na nálezisku 7 v Szarbii bolo objavených 14 žiarových jamkových hrobov (obr. 1), ktoré boli bud' bez výbavy (10 hrobov: 5, 6, 97, 98, 99, 102, 103, 104, 162, 163), alebo boli vybavené keramickými nádobami typickými pre skupinu Wyciąże (4 hroby: 14, 101, 116, 146).

Na objavenej časti eneolitického sídliska skupiny Wyciąże (obr. 1) bolo odkrytých 14 jám a čast' vel’mi rozsiahleho komplexu hliníkov (objekt 147). L’udské kostry sa našli v dvoch jamách: jedna kompletná v jame 36 (obr. 2: 1) a fragmenty d’alších dvoch $\mathrm{v}$ jame 23.
Súbor keramiky skupiny Wyciąże obsahuje: naberačky, džbány, amfory, poháre, hrnce, misy a vázy. Väčšina nádob úzko súvisí s polgárskymi tradíciami, predovšetkým kultúrou Bodrogkeresztúr.

Koexistencia rôznych foriem kostrového a žiarového (s urnou alebo bez urny) pochovávania je typickým fenoménom u periférnych skupín badenského kultúrneho komplexu.

Chronológia skupiny Wyciąże (obr. 5) je určená niekol'kými rádiouhlíkovými ${ }^{14} \mathrm{C}$ dátami, ktoré poukazujú na časové zaradenie medzi roky 3500-3350 pred n. 1 .

Integračným faktorom $\mathrm{v} 2$. polovici 4 . tisícročia p. $\mathrm{n}$. 1 . v Karpatskej kotline a v prilahlých oblastiach bola badenská kultúra. V oblastiach na sever od Karpát boli procesom „badenizácie“" podrobené niektoré skupiny kultúry s lievikovitými pohármi (Bronocice IV-V) a polgárska kultúra (skupina Wyciąże). 